\title{
China-Russia-India_-The BRICS Countries in Eurasia Are the Key Factors in the Construction of the Silk Road Economic Belt ${ }^{*}$
}

\author{
LI Xing, CHENG Zhi-jie \\ Beijing Normal University, Beijing, China
}

\begin{abstract}
China is the starting point and pioneer and driver of the Silk Road Economic Belt; Russia is located in the throat place of the belt; and India is at the joint of the belt and the Maritime Silk Road. China, Russia, and India as the BRICS countries are geo-connected, easy to reach a consensus because of their common and similar interests. The three countries also have common inherent demands and strategic directions: connectivity, complementarity, taking advantage of the great powers of Eurasia and sea-land compound, moving toward the grand trend of modern international economy and technology development. Promoting the construction of the Silk Road Economic Belt accords with their respective interests, and is their common interests, which decide that China, Russia, and India are the key factors and dominant forces in the construction of the belt.
\end{abstract}

Keywords: Silk Road Economic Belt, China-Russia-India, Eurasian BRICS countries

\section{Introduction}

The great powers are always the important force affecting the development of international relations, and the relationship of great powers is very important to the world development and international pattern. China, Russia, and India as the great powers of Eurasia continent and BRICS countries have a lot of influences in this region. As the representatives of new emerging great powers, they have the common demands of development. As the countries along the belt, they are the key factor of the construction of the Silk Road Economic Belt. The relationship of China, Russia, and India is the core of the construction of the belt.

\section{China, Russia and India as the BRICS Countries: Strong Strength, Complementary Advantages, Great Impact and Leading Capability}

China, Russia, and India as the great powers have important influence in their regions. As emerging powers, they have different advantages which are exactly complementary for the economic development.

\footnotetext{
* Acknowledgements: Project of National Social Science Foundation: "Studies on the Relations between the Silk Road Economic Belt and Eurasian Union" (14BGJ039); Beijing Philosophy and Social Science Planning Project: "Studies on the Relations between the Silk Road Economic Belt and Chinese Dream" (13KDB039); Major Project of Social Science of Tianjin Education Board: "Studies on the New Situation of the Game of the Great Powers in South Sea and Chinese Strategy" (2014ZD26); Project of State Key Laboratory (Tsinghua University) Open Foundation of Ministry of Science and Technology (sklhse-2014-A-03); supported by "the Fundamental Research Funds for the Central Universities".

LI Xing, Doctor of History, Professor, Director of Eurasian Studies, School of Government, Beijing Normal University.

CHENG Zhi-jie, Doctor of Politics, School of Government, Beijing Normal University.
} 
Russia has the advantage of energy. It plays a very important role in the world in energy storage and export. And it is the 2nd largest oil producer in the world after Saudi Arabia. Its oil storage capacity consists $12 \%-13 \%$ of the world total. Russian is of richest resource and most production, gas storage capacity of which consists $1 / 3$ of the world total. And Russia has the longest pipelines and the most export of the world. Russia has the largest global iron reserves, the 2nd largest global coal and aluminum reserves, the 7th largest global uranium reserves. And it is the 2nd largest producer of electricity power, hydro-power, and nuclear power equal, and the latter developed more rapidly. In contrast, China and India are the great powers of energy consumption, and need more. China has become the largest energy consumer. Indian overseas energy dependence is up to $70 \%$. Energy demand of China and India is the priority for their rapid and long economic development. They all emphasize the diversification strategy of energy sources to avoid the dependence on the Middle East's oil and their competition. So, there is huge space for cooperation between China, India, and Russia. At the same time, the relationship between Russia and the West has worsened because of the Ukraine issue. The latter imposed the sanctions on the former, which made Russia more and more need the East. China and India are important cooperation partners of Russia. Russia deepens the relationship with China and India by the virtue of its advantages, which can make three countries' cooperation deeper and deeper and reduce the pressure from the West effectively. The energy cooperation of three countries is that Russia exports energy to China and India, and China and India can invest in Russia for its energy infrastructure and exploring according to their economic superiority. In short, Russia is the upper hand to China and India in energy, and it can provide the energy for the construction of the Silk Road Economic Belt.

India, which is called "world office", has the advantage of technology. Indian comprehensive index of software export in scale, quality, and cost is the largest in the world, and India is the 2nd largest exporter after U.S. in the world according to the World Bank's investigation and assessment of national ability of software export. Indian advantage of software technology is the foundation of the related technology development. Although India lags behind China and Russia in the technology of military and space, software technology supports India for sustaining its economic development. Its advantage of software technology provides good conditions for other technological development. At present, due to problems of backward infrastructure and old technological facilities, Russia needs software technological to support its innovative development strategy which is beneficial to enhancing the quality of economic development; China has the gap with India in software technology which would encourage the development of strategic emerging industries, including new energy and information technology. In short, China, Russia, and India should enhance the cooperation in technology, complement each other, achieve common development, and shape their core technological advantages.

China has the advantage of capital which is mainly got from Chinese long-term export-oriented strategy. China has the largest global foreign exchange reserves, almost four thousand billion dollars after over 30-year's accumulation. It is the result of domestic huge production capacity and long-term low salary, and the organization capital is main. Capital has the nature of chasing the profits. China which has huge capital is moving toward the capital expansion with the emerging. China tries to conduct currency swap and currency settlement, and gradually expand RMB applicable scope because China is dissatisfied with U.S. dollar's hegemony. Currency circulation is one of the construction of the Silk Road Economic Belt, including the currency exchange and settlement under the current and capital account. Connectivity is the basic content of the construction of the belt. 
China can take advantages of capital and technology to support the construction of connectivity for countries and regions along the line (WANG, 2014). The construction of connectivity can provide the good conditions for the belt. In contrast, Russia and India are lack of capital. India always depends on the loans of World Bank, but gets less and less (ZHU, 2014). Capital outflow is normal in Russia, and becomes worse and worse under the prolonged Ukraine crisis. China can provide the capital for Russia and India through enhancing the relations of economy and trade and financial cooperation, and gives the guarantees to their economic development. In this respect, China and India have proposed the Bangladesh-China-India-Myanmar economic corridor; China and Russia have signed the Sino-Russian Eastern Gas Cooperation Project Memorandum and Contract of Sino-Russian Eastern Gas Buying and Selling, which are over four hundred billion dollars of total contract value, and they have proposed the plan of China-Russia-Mongolia economic corridor. The establishment of BRICS New Development Bank and the effort to establish the Shanghai Cooperation Organization Development Bank make the economic and financial relations of China, Russia, and India closer and closer.

Besides, Russia has the advantage of military, which can guarantee the security of the belt; India has the advantage of human resource, which can provide the talent for the belt; China has the advantage of manufacture, which can provide the goods for the belt.

\section{A Wide Variety of Cooperation Mechanisms of China-Russia-India: Interest Demand, Development Momentum and Strategic Prospect}

China, Russia, and India should strengthen the trilateral cooperation, and build the cooperation mechanisms of multilevel and wide field, with the bilateral and multilateral mechanisms of Sino-Russian strategic cooperative partnership, Sino-Indian strategic partnership, SCO and BRICS.

\section{“Moscow-New Deli-Beijing Strategic Triangle”}

In December 1998, former Russian Prime Minister Primakov hoped to build the "Moscow-New Deli-Beijing Strategic Triangle" when he formally visited India. Actually, it is the inheritance of his thought which was called the China-Russia-Indian strategic cooperation as the Foreign Minister of Russia in 1996.

Russia is a country good at innovating in diplomacy. And it has proposed the well-known Energy Diplomacy, Wisdom Diplomacy, and Network Diplomacy. China-Russia-Indian strategic relations have been proposed by Russia first. Firstly, Russia has the historic tradition of expansion. During the expanding, Russia was stubborn and tactical facing the more powerful states and nations, which could achieve its target and maintain its strength from loss. Secondly, realistic territorial expansion from the historic inertia and for the security demand more can give Russia strategic depth and safeguard its security. Russia tried to build the "Stable Arc" around it after the collapse of Soviet Union (LI, 2005). Russia wanted to get the equal status of great power after its independence (LO, 2014). Russia continues to exert its tradition of perpendicular and horizontal diplomacy, and makes up its deficiencies of strength relying on its smart and wisdom diplomatic policy under its limitation of strength and deficiencies of ability (XIAO, 2012). Thirdly, Russia gets its own judgment on the international situation. According to The Concept of Foreign Policy of Russian Federation 2013, the nature of transformation of international system is shaping the multipolar ones; the focus of world development turns to the East; the way of alliance has been substituted by the network diplomacy of multilateral and effective mechanisms beneficial to solving the common tasks in international affairs; Russia pursues the all-around diplomatic approach, and 
explores the relations with major states and national groups actively and so on (HUANG, 2014). Russia is adjusting its foreign policy continuously to adapt to the changing international society and maintain its international status. Therefore, it is necessary to propose the China-Russia-Indian strategic triangle by Russia.

After proposing the concept of China-Russia-Indian strategic triangle, Russia promoted the scholars' dialogue and communication of three countries firstly. In September 2001, scholars from China Institute of International Studies, Russian Far East Institute of Academy of Science and Indian Institute of Chinese Studies held the first three party academic conference in Moscow. It has been held 13 times until now, and has become the connection mechanism of China, Russia, and India. This mechanism is rotated by one of three countries each year, three institutes above hold the conferences in turn. On the basis of it, China-Russia-Indian foreign ministers meeting has been held and institutionalized. The 1st three countries' foreign ministers meeting was held in 2002; the 9th meeting in 2009 signed the joint communique which included the discussion and coordination on the global and regional major issues.

The relations of China, Russia and India have new development in the new century, which is from the strategic demand of three countries' national interests. For China, the relations of China-Russia can safeguard the security of Northwest China, the relations of China-India can safeguard the security of Southwest China. For Russia, the strategic cooperation with China and India can guarantee its status of great power, and exert its advantages in the competition with U.S. and Europe. For India, it is not available to achieve its appeal alone after rising. The thoughts of three countries reveal their stances on the relations of strategic triangle: China is prudent, Russia active, India suspensory. Coordination and cooperation of global and regional issues are the priorities of China-Russia-Indian strategic cooperation, but the level of their cooperation mechanisms is low and the nongovernmental ones are primary. In short, China, Russia, and India as the representatives of new emerging great powers are facing the international order which is led by the West after their rising. But, their appeals are not satisfied under this situation, which leads to the competition with the West.

\section{China-Russia-Indian Trilateral Cooperation Mechanisms}

The main of China-Russia-Indian trilateral cooperation mechanisms is the foreign ministers meeting which is regarded as the core, others are the dialogue and communication mechanisms of all levels and fields, for example, academic conferences, disaster relief experts meeting, entrepreneurs meeting, consultation of regional division of foreign ministry, agriculture cooperation forum, geo-strategy trend seminar of officers and scholars, medicine, and health experts meeting and so on. The fields refer to thinking tanks, business, agriculture, disaster relief, medicine, health, etc. They are all active cooperative mechanisms, led by governments and followed by nongovernmental mechanisms.

BRICS is one of multilateral mechanisms which embrace China, Russia, and India. It has some main pragmatic and multi-levels mechanisms: Leaders Summit Meeting, National Security Advisers Meeting, Foreign Ministers Meeting, Professional Ministers Meeting, Sherpas Meeting, Non-Periodical Communication of the Permanent Envoys of Multilateral Institutions, Business Council, Think Tanks Council, and more professional fields. In July 2014, the New Development Bank was established formally, which is an event of BRICS cooperation process (ZHU, July 24th 2014), and is the beginning of BRICS institutionalization (MEI, 2013). There are China-Russia-Indian mechanisms and India-Brazil-South African forum involved by member states 
under BRICS. The latter has some specific mechanisms as below: leaders summit as the core, joint business council, defense cooperation dialogue, three-side committee (foreign ministers), trust fund, which have promoted the cooperation of energy, military, trade, and the permanent members of UN Security Council. In contrast, the level of China-Russia-Indian cooperation mechanism is lower, mainly bilateral cooperation, lack of effectiveness.

There are two approaches to deepen their cooperation: The first one is maintaining and developing the existing mechanisms, for example, UN, G20, BRICS, and SCO, strengthening their coordination in them as their core task. China and Russia have been the permanent members of UN Security Council, and have important influence on international politics in the world. But India is not, and has been the non-permanent member of Security Council many times. India has become stronger and stronger now, and has the enthusiasm of handling the international affairs, promotes the reform of Security Council and wants to be the permanent member. G20 is the premier forum of international economic cooperation, and China, Russia, and India are important members. The competition between the Western great powers and the new emerging economics in G20, mainly focuses on the reform of international financial institutions, especially IMF's quota and governance structure. China, Russia, and India as the representatives of new emerging great powers have the same appeals and stances. With the establishment of New Development Bank, BRICS has become the important mechanism of guaranteeing the appeals of new emerging great powers and developing countries. They as the developing countries want to develop, and need a multilateral mechanism to solve the problems. BRICS is the most appropriate mechanism. SCO is an important mechanism of China and Russia for Central Asian security, India shall be the formal member state. SCO should become the platform of regional security and development for China, Russia and India. Russia wanted to enlarge the SCO. Russian foreign minister Lavrov has said, SCO summit should make the decision, and permit to open the process of organization enlargement in Russian presidency (ZHAI, 2014). China has agreed. In September 2014, SCO Dushanbe summit has decided that India should be the member of organization. UN, G20, BRICS, and SCO have become more mature and perfect than China-Russia-Indian mechanism. China, Russia, and India not only use them and strengthen the cooperation, but also absorb their mature experience as reference for the development of China-Russia-Indian mechanism.

The second one is improving their cooperation levels and deepening their cooperation fields. China-Russia-Indian mechanism gets the core of foreign ministers meeting, and includes the dialogue and communication mechanisms of all levels and fields. For three countries, nations and governments' promotion is the most important, and it is necessary to set up the leaders meeting. Firstly, leaders meeting can be held in the existing mechanisms, for example, UN, G20, BRICS, and SCO; Secondly, leaders meeting can be held regularly on the basis of foreign ministers meeting. The three countries' leaders meeting is beneficial to promote the cooperation in the highest level, and the effective cooperation in wider fields. Meanwhile, broadening the fields of cooperation is necessary, especially economy and finance as the core. Economic cooperation is the complementarity of their advantages and the deeper international one. Russian energy, Indian technology and Chinese capital shall promote the economic development effectively. Their advantages are not limited to themselves but can influence the regions and the whole world. Firstly, Central Asia is adjacent to China, Russia and India, and clips in their middle, but full of poorness and contradictions. Central Asia will be one of their instability if there are no effective means and measures to relive the contradictions and improve local people's 
life. Therefore, the development of Central Asia and local economy preferentially will relive the contradictions and make three countries and the region peaceful and stable. Secondly, new emerging states want to reform because of the dissatisfaction with the existing international financial order. But the West stands in the way. So, they who want the reform of international financial order and guarantee the development of new emerging and developing states, get united only to self protection and self development, which is reflected on the establishment of BRICS New Development Bank, ongoing developing of Asia Infrastructure Investment Bank and Silk Road Fund. The cooperation of economy deepens the three countries' relationship, and improves their global influence.

\section{China, Russia and India as the BRICS Countries: A Lot of Commons and Similar Interests, Good Interrelation}

China, Russia, and India as the Eurasian BRICS countries have some commons. Firstly, they have the similar status and situation in the international pattern. In term of the development stage, they all belong to the developing countries. And after developing some years, all become the new emerging economies of international society. Now they have improved their economy and status, and play an important role in the regional development. In term of the development level, they all are regarded as "Third World" countries by the "First World", and "First World" countries by "Third World" (LI, 2009). ${ }^{1}$ But their developments are mainly reflected by the economy, and their comprehensive strength can't compete with the developed countries. BRICS unlike G7 can't make indiscreet remarks or criticisms on the international regimes. It is a mechanism of competition, which can guarantee their interests, with the developed countries in the world. It is a very vivid description that BRICS's front foot has stepped in the first world, rear foot in the third world, and body in the second world. Their strength and status surpass the third world's countries, and have the gap with the first world, which is called "the third world of the first one", "the first world of the third one". They all think they are the great powers, but the West think they are the exception, and they have the characteristic of "BRICS economy" obviously.

Secondly, they want the political multi-polarization, influence, and voice. States must safeguard their achievements, and pursue their corresponding status with their strength improvement, especially safeguarding their national interests as the core. The national interests are different, "survival is the core interest firstly, secondly economy and development interest, finally national prestige, which is the ability of controlling other nations" (LI \& LIU, 2011). They are reflected in the BRICS obviously. Otherwise, the current international political and economic mechanisms are guided by the U.S.-led West. Especially, the international economic mechanisms where the developing countries have very little quota and influence, are comprised of some international organizations led by the developed countries. It is unfair for the new emerging market countries. As a result, BRICS countries want the political multi-polarization in order to change U.S. hegemony and the Western dominance of international regimes; BRICS countries want to show their power, and improve their influence and voice, which all show that they have the similar thoughts. Therefore, they have the characteristic of "BRICS diplomacy" obviously.

Thirdly, they want to settle the international disputes by negotiation and diplomacy without interference in internal affairs, which are showed by the The Five Principles of Peaceful Coexistence initiated by China and

\footnotetext{
1 See Трасформация мирового порядка и внешняя политика Китая (The transformation of the world order and China's foreign policy) (2012), Сравнительная Политика (Comparative Politics), (1).
} 
India together and the Syrian issue. The Five Principles of Peaceful Coexistence is the basic principles of dealing with the relationship between countries proposed by China, and becomes the important guidelines of international relations initiated by China and India, China and Myanmar together. It contains the following: "mutual respect for sovereignty and territorial integrity, non mutual aggression, non interference in each other's internal affairs". These principles are applicable for the same status countries as well as the hegemony and the weak states. In the early days of 21 century, the West launched The Color Revolution in the Middle East and North Africa under the name of democracy, which made Tunisian, Egyptian, and Libyan regimes changed. The West wanted to do it on Syria. In August 2013, the U.S. claimed that they would fight with Syria, and got support from France and the U.K. But the international society except the West is against, and asked them to abandon the fighting interference and deal it with negotiation and diplomacy. In BRICS countries, China and Russia as the permanent members of UN Security Council firmly opposed, and Brazil, India, South Africa also opposed the Western action. Finally, U.S. abandoned the action under the contest of all parties, especially the Russian effort.

Fourthly, they want the democratization of international relations, opposing the hegemony and unfair international political and economic order. The new emerging market countries want the status equaled with their strength, but it is very difficult under the U.S. hegemony. The BRICS countries always ask the democratization of international relations and anti-hegemony. The specific is as follows: changing the unfair international political and economic order and showing the strength of new emerging market countries. The most important global financial mechanisms are International Monetary Fund and World Bank. The former is under the control of the U.S., and the U.S. has the right of one vote veto. In view of this, BRICS countries have asked for quota reform as well as implementation many times in order to "formulate a new formula for reflecting the weight of world economy", 2 and show the trend of world economic multi-polarization in the governance and decision-making mechanisms of the latter (WANG, 2012). They want to promote the reform of international currency system and change the U.S. dollar's position. The democratization of international relations is a macro understanding. Its realization not only depends on their power and joint mechanisms, but also on changing the unfair and undemocratic international regimes and rules on the basis of the former, even changing the international organizations. Only in this way, the democratization of international relations can be achieved. So do BRICS countries. BRICS countries hate and love the West: There are hates between them, BRICS hate, but can't leave the West. Improving the relationship with the West is their priority. They don not have enough confidence to struggle with them for lack of power and capital of cooperation. They have the similar development stage and mission, and would provide the non-western development road for the world. They have the characteristic of "BRICS road".

Fifthly, they don't want direct conflicts with the United States. BRICS countries need to protect their sovereignty and security, economic and development interests after their rising. U.S. as the only super power in the modern world has the incomparable advantages of military, economy, and technology. Although most of the countries and international organizations including BRICS oppose American hegemony after the Cold War, few of them have conflict with the US directly. The European Union as an American ally has been suppressed because of its integration and euro, which worsen the European debt crisis. "American rating agencies always do

\footnotetext{
${ }^{2}$ Xinhua News Agency, St. Petersburg, 5 September, 2013.
} 
something to reduce the effect of rescue measures when EU put forward the big move" (MEI, 2012). BRICS countries except Russia which country has worsen the relationship with U.S., as the new emerging economies, don't want to have conflicts with the U.S., because the U.S. has the absolute power and ability to make them loss. So, besides that BRICS countries should combat with the U.S. wisely in the world, heating together is the smart choice.

Sixthly, they are all the regional centers, and play the important roles in regional governance. BRICS countries are the representatives of the developing ones of continents, and play an important role in the regional development. Russia is the core power of Eastern Europe and North Asia; India has the world's second largest population, and has the impressive power of military and technology after 20-year's rapid development; China is the second largest economy in the world, and will become the first one in the first 50 years of this century estimated conservatively. BRICS countries are all the regional centers, the top of the developing ones, and play an important role in regional governance. They can be called the polars of world multi-polarization, the powers of big great ones. The father of BRICS, Jim O'Neil, has predicted that there are four of BRICS countries in top six of world economy in 2050.

Seventhly, they are all in the transformation stage up to high income countries. The standard is provided by the World Bank, as follows: The state of which the per capita national income is below 995 U.S. dollars is low income one, 996-3,945 dollars below average income one, 3,946-12,195 dollars above average income one, above 12,196 dollars high income one. According to this standard, Russia has been the high income state, China is above average income state, India is below average income state. So, China and India are middle income countries. They should avoid the middle income trap. The following performance of the middle income trap countries, which includes the division of class, the rich and the poor; income inequality; corruption; power rent seeking; and social contradictions. During this stage, the country needs anti-corruption; if not doing well, the result is the stagnation or backwardness of economy and society.

Eightly, they have the energy complementarity. BRICS countries' demand for energy is obvious because they are the most dynamic economies. China and India are the energy importing countries, Russia the energy exporting country, which make the energy complementary, for example, energy's supply and demand, security, exploring the new energy, the development of energy technology, and global energy order of governance. The complementarity is showed on the bilateral and the multilateral relations, and the BRICS energy cooperation mechanisms are necessary. "In fact, in 2010, Russia has suggested the BRICS energy cooperation mechanisms" (ZHANG, 2013). Just like BRICS New Development Bank, BRICS can establish the energy cooperation mechanisms in order to transform the existing energy pattern.

In brief, China, Russia, and India have the same or similar situation and status in international economic and political patterns, which makes them easily to reach a consensus. On the basis of it, their relations will endure.

\section{China, Russia, and India as the BRICS Countries: Strong Self-reliance, External Factors Are Not Decisive}

The culture of China-Russia-India is comprised of the East and the West, Asia and Europe, interaction, communication, mixture, learning and influencing each other. They all advocate the multi-polarization, democratization, and multilateralism, oppose the hegemonism and unilateralism, the Western action of foisting 
their opinion upon others and interfering others' internal affairs with military, propose the independent development and diplomatic routes, want to become the polars of the world because of equality, diversity, and inclusion of the culture.

The three countries advocate the diversity of development because of characteristic, particularity, and complexity of the cultural development. The right and wrong all exist together in the international relations. Cooperation, adjustment, negotiation, mutual benefit and win-win, multiplex symbiosis, harmony not sameness, and dialogue not conflict are necessary. They excavate their own resource of culture, nations, and history, criticize the Western Center and Superiority of the West because of representative and equality of the culture. They are the representative nations of the Eastern culture different to the Western one of Anglo-Saxon Christian civilization (Christianity, freedom and democracy, market economy). External factors especially the West including U.S., Europe and Japan play certain role, but not decisive. The decisive factors are from Asia-European continent own, especially their own and internal interests.

China and India have some similarities: history, civilization, population, and development. Although they have differences: China was once a colonial and semi-colonial country, India a colonial one; China a socialism country, India a capitalism one, they have more commonalities. They both need national sovereignty, security, and independence, were both bullied but do not want to bully other countries, initiated together the Five Principles of Peaceful Coexistence, insist on the non-alignment, and moderate diplomacy.

The differences between BRICS and G7 are as follows: (1) development stage. G7 countries have already achieved industrialization, BRICS countries are in the process of industrialization; (2) interests. G7 countries want to safeguard the international system and international regimes of their dominance, BRICS countries think that the existing international system and international regimes, which don't show their strength, interests and appeals, are unfair; (3) development trend. The effect and influence of G7 are declining. The global governance of G7 has begun to decline from 1990s (XU, 2013). G20 leaders' statement has announced that G20 instead of G7 is the premier forum of the cooperation and coordination of international economy in 2009. G7 focuses mainly on the international security and diplomacy. BRICS has improved their effect and influence, contests with the West to guarantee its interests. The institutionalization of BRICS has made progress, for example, the New Development Bank.

China, Russia, and India as the BRICS countries have the commons of institutionalization. In March 2013, the fifth summit of BRICS leaders decided to establish the New Development Bank, ready to found the Contingent Reserve Arrangement, establish the BRICS business council. The initial authorized capital of New Development Bank is one hundred billion dollars, the initial subscribed capital is fifty billion dollars equally distributed amongst the founding members. The Bank has its headquarters in Shanghai, the first President of Bank is from India, the first chairman of Board of Governors is from Russia, and the first chairman of Board of Directorsis from Brazil. In November 2014, the informal meeting of BRICS leaders in G20 leaders' summit got some commons again, as follows: the establishment of New Development Bank and Contingent Reserve Arrangement as soon as possible, criticism of the delay of IMF reform because of U.S., wishing to improve their representation and voice. BRICS countries are deepening their multi-level communication and cooperation, including the internal pragmatic cooperation and external communication. 
After the new administration came to power, China has changed the geo-development patterns of east-fast and west-slow, sea-strong and land-weak, put forward the Silk Road Economic Belt, founded the Silk Road Fund, which can make all-around, no enemies diplomacy in order to realize east-west and sea-land balance. India looks east and concerns the other side of the neighbors-Middle Asia, wants to get the balance between the great powers. Russia focuses on the construction of Eurasian Union (LI, 2013), and changes its diplomacy from facing the West to turning to the East after the outbreak of Ukraine issue. With the transfer of the core of world economy and politics towards Asia-Pacific region, looking east has become the common feature of China, Russia, India, and other BRICS countries.

China, Russia and India are great powers which have the tradition of independent diplomacy. China and Russia are the permanent members of UN Security Council, insist on independence, and India is not American pawn. For example, China and India didn't impose sanctions against Russia with U.S. and the West on the Ukraine and Crimea issues. On 18 March 2014, Putin delivered a speech in the Kremlin and said:

We thank the people who understand Russian measures on the Crimea issue. Thanks Chinese people. Chinese leaders always look at the situation of Ukraine and Crimea with the historic and political view. We speak highly of Indian restraint and objective attitude. (March 20, 2014)

India is the first great power which admitted that Russia recovered its sovereignty on Crimea. China didn't follow and opposed the Western economic sanctions on Russia, didn't think that sanctions would be available, and deepened the cooperation in economy and energy with Russia. China-Russian strategic cooperation partnership has made great progress.

\section{Conclusion}

The Silk Road Economic Belt, serving as the vacuum zone of the economic development of Eurasian continent, has a huge development space. But there are some questions followed: the disputes of religion, nations and territories, the competition of the great powers, and the serious "Three Evil Forces". China, Russia, and India as three regional great powers close to the belt have competition and cooperation. Their alliance will decide the development direction of the Eurasian continent and the belt. The priority is exerting their advantages which will safeguard the belt. The advantages are the capital, energy, and technology, which are the core of promoting economic development. Moreover, Russia would provide the security, India talents, and China goods. China, Russia, and India would set up the normalized mechanisms of senior officials and working groups, hold the regular or irregular dialogue and communication, which favor their smooth contacts. They should deepen their nongovernmental mechanisms and strengthen the communication of folk culture, economy and others, which build the nongovernmental basis of their cooperation.

In November 2014, Chinese President XI gave a speech of Connectivity for Development Partnership for Cooperation in the Dialogue on Strengthening Connectivity Partnership. XI said that China would establish the Silk Road Fund and AIIB for the Silk Road Economic Belt and the 21st Century Maritime Silk Road ("One Belt, One Road"). They all mean that "One Belt, One Road" has become the most important and medium and long-term development strategy. Russia and India as the BRICS countries belong to Eurasian continent with

\footnotetext{
${ }^{3}$ See from http://china.cankaoxiaoxi.com/2014/0320/363272.shtml.
} 
China, are the top-drawer countries of Chinese north and south. There are complementarity and mutual benefits between China and them, but connectivity not. It is obvious that Russia and India are the keys of the construction of the Silk Road Economic Belt.

China, Russia, and India are the Asian and European great powers of sea-land, geographically connected, close to the Pacific, Indian ocean, and Arctic ocean; are the members of SCO, BRICS, CICA (Conference on Interaction and Confidence-Building Measures in Asia) and G20, on the Silk Road Economic Belt, and the members of the belt framework and ASEAN " $10+8$ ". Middle Asia in the core and hub of the belt locates in the place between China, Russia, and India. The relationship between the Middle Asia and China, Russia, and India is close: the growing economy and trade linkage of China and Middle Asia, the traditional history and military relations of Russia and Middle Asia, the long history and culture standing of India and Middle Asia. Their relationship has influenced the central and marginal zones, including the Middle East, East Europe, Caspian-Caucasus region, even the West Europe.

China is the starting point of the Silk Road Economic Belt, and advocated and pushes the concept of the belt; Russia is at the throat position; India locates at the joint of the belt and the Maritime Silk Road. China, Russia, and India have the leading capability and have the engine and demands because of their strong power and great influence. They reach the consensus easily and their relationship will be expected because of their common or similar interests. Moreover, they all have the independent diplomatic tradition, do something independently, which make foreign factors not decisive. They keep connectivity and complementarity, exert the advantages of sea-land compound. They show the new trends of world economy and technology development as follows: the weight of sea power declines, land power ascends; sea and land get balance, not former imbalance; east and west get the same importance, not stress; south and north are taken into account equally, not deviation with the breakthrough of high speed and other technology. The new trends above are their common demands and strategic direction. The construction of the belt is their respective interests, also their common interests, which decide that China, Russia, and India are the key factors and dominant powers, encourage them to strengthen the cooperation, no differences, contradiction, and conflict. And it is normal that there are differences, contradiction, and conflict between the great powers. It is inevitable. We should focus on the main aspects of contradiction. Prime Minister LI has said: a few of clouds can not stop the rainbow eventually. All in all, China, Russia and India as the BRICS countries are the key powers and locomotives of the construction of the Silk Road Economic Belt, their relations are the core of the construction of the Silk Road Economic Belt.

\section{References}

Attention from foreign medias on Putin's thanks to the Chinese people. (March, 20th 2014). Retrieved from http://china.cankaoxiaoxi.com/2014/0320/363272.shtml

HUANG, D. X. (2014). Reviews on the New concept of foreign policy of Russian Federation — On the Russian diplomatic trend in Putin's new term. Russian Studies, (1).

LI, X. (2005). The Eurasian factor of the relations of Russia-U.S. after the Cold War. Studies of International Politics, (3).

LI, X. (2009). Reflection on the changing of international order and Chinese action. Contemporary International Relations, (11).

LI, X. (2013). Eurasian Union: Putin's new strategy of diplomacy. Expanding Horizons, (5).

LI, X., \& LIU, J. (2011). An analysis of the Russian-American games from the perspective of their domestic politics. Current Affairs Press, (14).

LO, B. B. (2014). Russia, China and the United States: From strategic triangularism to the post-modern triangle. Russian Studies, (1). 
MEI, X. Y. (2013). Financial cooperation: The beginning of BRICS mechanism's institutionalization. Reports on Current Events, (5).

MEI, Z. R. (2012). The complexity of European debt crisis and the future of EU. Germany Studies, (1).

WANG, H. Y. (2014). The construction of the Silk Road Economic Belt encourages the common development of regional countries. Academic Journal of Russian Studies, (1).

WANG, W. (2012). New trend of BRICS multilateral economic cooperation. Asia-Pacific Economy Review, (2).

XIAO, H. Z. (2012). An analysis of problems of Russian diplomacy towards the BRICS countries. Russian Studies, (4).

XU, H. C. (2013). Exerting the role of G8, G20 and BRICS in the global governance. Analysis and Outlook of International Economy.

ZHAI, L. M. (sptember 11th, 2014). Russian foreign minister: SCO shall open the process of organization enlargement in Russian presidency. Huanqiu. Retrieved from http://world.huanqiu.com/exclusive/2014-09/5133264.html

ZHANG, C. Y. (April 2nd, 2013). General trend of building the BRICS energy cooperation mechanisms. China Petroleum Daily.

ZHU, J. J. (2014). The transformation of BRICS cooperation mechanism. International Review, (3).

ZHU, J. J. (July 24th, 2014). The wisdom of institutional design of BRICS Bank. Shanghai Securities News.

Трасформация мирового порядка и внешняя политика Китая (The transformation of the world order and China's foreign policy). (2012). Сравнительная Политика (Comparative Politics), (1). 